\title{
Updating Hazard Identification, Risk Assessment, and Determining Control (HIRADC) Document: Case Study at Schneider Electric Cikarang, Indonesia
}

\section{Christoffer Halim¹, Jani Rahardjo ${ }^{1}$, and Hasoloan Haery lan Pieter²}

${ }^{1}$ Industrial Engineering, Petra Christian University, Jl. Siwalankerto No.121-131, Surabaya 60236, East Java, Indonesia

${ }^{2}$ Faculty of Technology Management \& Technopreneurship (FPTT), Hang Tuah Jaya, Universiti Teknikal Malaysia Melaka (UTeM), Melaka 75300, Malaysia

\section{Abstract}

Occupational Health and Safety plays a crucial role in the institution or organization. The purpose of Occupational Health and Safety (OHSAS) is to ensure the health and safety of the work. To fulfil the purpose, the institution or organization need to have a good work safety and health management system. OHSAS 18001: 2007 is an

Corresponding Author:

Jani Rahardjo

jani@petra.ac.id

Received: 16 February 2020

Accepted: 5 March 2020

Published: 10 March 2020

Publishing services provided by

Knowledge E

(c) Christoffer Halim et al. This article is distributed under the terms of the

Attribution License, which

permits unrestricted use and redistribution provided that the original author and source are credited.

Selection and Peer-review under the responsibility of the ICLBI (2018) Conference Committee. international standard for the implementation of work safety and health management system. One of the clauses contained in OHSAS 18001: 2007 are hazard identification, risk assessment, and determining controls and these can be documented in the HIRADC (Hazard identification, risk assessment, and determining control) document. HIRADC is divided into three parts: Hazard Identification, Risk Assessment, and Determining Control. HIRADC, which is annually reviewed and updated by the management, discovers and controls the potential hazards that exist around the working environment. It goes in line with OSHAS 18001:2007 and ISO 14001:2004.

Keywords: Risk management, Safety and Health Management System, workplace hazard

\section{Introduction}

Schneider Electric Cikarang is located at East Jakarta Industrial Park (EJIP) Plot 4B1-B2, South Cikarang, Bekasi, West Java, Indonesia. Schneider Electric Cikarang is one of the few factories that Schneider Electric Indonesia have and producing electronics, for example LV Panel, MC Set, PIX, SM6, etc. Schneider Electric Cikarang have a vision to be the global specialist in energy management, and the purpose is every energy user can feel safe, reliable, efficient, productive, and environmental friendly.

Schneider Electric Cikarang always doing continuous improvement to increase the costumer and worker satisfaction. Currently Schneider Electric Cikarang have more than 1000 workers, and still counting every year. Production of Schneider Electric Cikarang 
Indonesia contribute as $62 \%$ to production Schneider Electric. The rest is distributed to the countries in Asia, like Malaysia, Singapore, Australia, etc.

Schneider Electric Cikarang have some system management certification, like ISO 9001, ISO 50001, and in 2013 Schneider Electric Cikarang got an achievement as manufacture industries that have a good and consistent performance in implementing Indonesia's national standards at SNI Awards event. Schneider Electric Cikarang not only focus on the customer satisfaction, but also the worker satisfaction. This thing can be proven by the exist of SERE (Safety, Environment, Real Estate) Department. SERE Department main job is to ensure the work is harmless for the worker. First aid historical data in Schneider Electric Cikarang on 2017 shows that 40 \% work accident caused by the process can't be processed using the PPE and $60 \%$ work accident caused by the operator exposed to a sharp plate because the operator not using PPE. The accident must be decreased on the next year to fulfil the SERE Department objectives. In order to decrease the accident that occurs in the process, a HIRADC (Hazard Identification, Risk Assessment, and Determining Control) method is needed to controls the potential hazards that exist around the working environment. The research addressed two questions. First, what is the update for HIRADC 2018 Document? Second, what is the right way to control the potential hazard? This research aims to update HIRADC document based on the current condition, and determine the right risk control to reduce potential hazard that exist around the working environment

\section{Conceptual models}

Today's companies have variety of solutions that can decrease the potential hazard that exist around the working environment. HIRADC assessment one of innovation that can reduce the potential hazard in the working environment. This research using HIRADC assessment as the key to decrease the potential hazard that exist in the working environment. Conceptual models in this research is given in Figure 1 based on conceptual modeling [1].

In HIRADC assessment, SERE Department have the roles to manage HIRADC assessment until all department understand the importance of HIRADC and involved in the assessment. Each party that involves in the process can also connecting with HIRADC assessment. The health and safety of the worker will increase, the process more efficient and effective, and increasing the worker involvement in the company health and safety program [2]. 


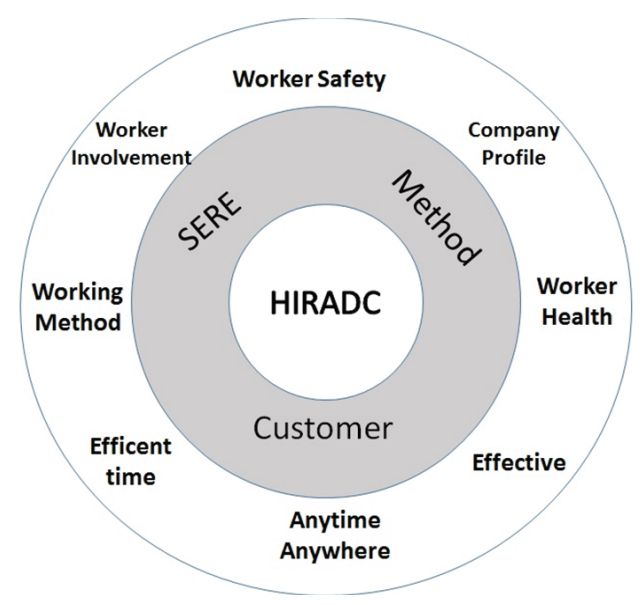

Figure 1: Conceptual models

\section{Research methodology}

\subsection{Health and safety management system (HSMS)}

HSMS is the part of the organization management system that used to develop, realizing work safety policy, and control the risk of work safety in the organization [3]. OHSAS 18001:2007 and ISO 14001:2004 shows that the implementation of HSMS is the way to analyze a risk from a job. The benefit from implementing HSMS are [4]:

1. Shows the company compliance for the government rules about company responsibility to protect every worker.

2. Reduce cost that come from the work accident.

3. Create the effective management system that so every work process have a clear objectives and coordinated.

4. Increase the worker and customer satisfaction.

\subsection{OHSAS 18001:2007}

OHSAS 18001:2007 is a document or certificate from British Standards Institute (BSI) to set the applied HSMS in the company. OHSAS 18001:2007 requirements applied for all kind of organization without looking the size of its company. The purpose of OHSAS 18001:2007 is to prevent work accident in the working environment [5]. 


\subsection{ISO 14001:2004}

ISO 14001:2004 is an international standard from International Organization for Standardization that organize about environment management system. Environment Management System (EMS) are one of a few management system components. A few points in ISO 14001:2004 are: organization structure, activity plan, responsibility, training, procedure, process development, and compliance to the environment policy [6].

\subsection{Hazard identification, risk assessment, and determining con- trol (HIRADC)}

HIRADC have a tight relationship with OHSAS 18001:2007 (clausal 4.3.1) and ISO 14001:2004. The result from HIRADC assessment is used to define the health and safety purpose that the company wants to achieve. The HIRADC assessment can help the company to find the potential hazard in the working environment [7].

\subsection{Hazards identification}

Hazard identification is use to know the potential hazard in the working environment. In this stage the company will find all the risk or hazards in the working environment. This potential hazard must be founded before causing any impact for the company [8].

\subsection{Risk assessment}

Potential hazard that founded on the hazard identification stage will be scored in this stage. The purpose of the scoring is to define the risk level of the hazards. This risk assessment is guided by Australian Standard/New Zealand Standard for Risk Management [9]. This risk assessment considers two factor, there is probability and severity [10]. Scale of the scoring can be seen at Table 1, Table 2, and Table 3.

TABLE 1: Probability scale AS/NZS 4360 standard.

\begin{tabular}{ll|} 
Level & Description \\
1 & Insignificant \\
2 & Minor \\
3 & Moderate \\
4 & Major \\
5 & Catastrophic \\
\hline
\end{tabular}


TABLE 2: Severity scale AS/NZS 4360 standard.

\begin{tabular}{lll} 
Level & Description \\
1 & Rare \\
2 & Unlikely \\
3 & Possible \\
\hline 4 & Likely \\
5 & Almost Certain \\
\hline
\end{tabular}

TABLE 3: Risk matrix scale AS/NZS 4360 standard.

\begin{tabular}{|l|c|c|c|c|c|}
\hline Risk Frequency & \multicolumn{5}{|c}{ Risk Level Description } \\
\hline & $\mathbf{1}$ & $\mathbf{2}$ & $\mathbf{3}$ & $\mathbf{4}$ & $\mathbf{5}$ \\
\hline 1 & L & L & M & M & H \\
\hline 2 & L & L & M & M & H \\
\hline 3 & L & M & H & H & H \\
\hline 4 & M & M & H & H & E \\
\hline 5 & M & H & H & E & E \\
\hline
\end{tabular}

\section{Findings}

HIRADC assessment is begin with hazard identification in all process and activity at Schneider Electric Cikarang. Every potential hazard will be analyze in risk assessment process. The result from risk assessment will be used as the trigger for scoring the risk.

\subsection{Data collection}

Hazard identification is applied to all process and activity in Schneider Electric Cikarang. Hazard identification can be executed by doing interview, observation, and historical data. The interview is held within the operator, supervisor, manager, and all staff. Historical data that was used is the first aid data at Schneider Electric Cikarang on 2017. First aid document at Schneider Electric Cikarang 2017 is given on Table 4. 
TABLE 4: First aid document at Schneider Electric Cikarang 2017

\begin{tabular}{|c|c|c|c|c|c|}
\hline No & Date & Cause & Department & Victim's Name & Leader \\
\hline 1 & April, 13 & $\begin{array}{l}\text { Do not use Personal } \\
\text { Protective Equipment } \\
\text { (PPE), Sharp plate }\end{array}$ & Production SM6 & Suciawan & Suprapto \\
\hline 2 & May, 6 & $\begin{array}{l}\text { Do not use PPE, Sharp } \\
\text { plate }\end{array}$ & Warehouse & Otim & Amiadji \\
\hline 3 & July, 31 & Bruising on the hands & $\begin{array}{l}\text { Project } \\
\text { Management (PM) }\end{array}$ & Risma & Marigan \\
\hline 4 & September, 15 & $\begin{array}{l}\text { Do not use PPE, Sharp } \\
\text { plate }\end{array}$ & Production SM6 & Aditya & Aris Budianto \\
\hline 5 & December, 20 & Motor Driving, Slip & Adaptation & Syawaldi & Suyono \\
\hline
\end{tabular}

\subsection{HIRADC analysis}

Risk assessment (guided by Australian Standard/New Zealand Standard for Risk Management (AS/NZS 4360:2004)) is held for all process in the company. This step considers likelihood and severity. Risk assessment is held for every hazard that founded by interview, observation, historical data, and brainstorming. Potential hazard in level moderate, high, and extremely high must be executed immediately because the process could harm the workers. The result of HIRADC analysis in all activities at Schneider Electric Cikarang is given on Table 5 .

From the HIRADC analysis result, $75.68 \%$ of all potential hazard are on the low risk level, $24.19 \%$ on risk level moderate, and $95 \%$ risk level moderate is caused by the operator rolls up the sleeve, because of that the operator can be harm because of the sharp metal part. High risk level is as $0.13 \%$ will be processed on the OTP (objectives, target, and programs of department) document.

\subsection{Change in HIRADC document 2018}

The change on process or activity can be happen at all time, because of that there's some change that happen from HIRADC document 2017 to HIRADC document 2018. The change of the process or activity is given on Table 6 .

TABLE 6: HIRADC Analysis Result

$\begin{array}{lll}\text { No. } & \text { HIRADC } 2017 & \text { HIRADC } 2018 \\ 1 & \begin{array}{l}\text { There's no assembly shutter mechanic } \\ \text { process on the jig (Assy joint frame cassette- } \\ \text { MC Set) }\end{array} & \begin{array}{l}\text { Additional process assembly shutter } \\ \text { mechanic at jig (Assy joint frame cassette-MC } \\ \text { Set) }\end{array} \\ 2 & \begin{array}{l}\text { Move panel with skate trolley to FQC } \\ \text { area(SM6 SW) }\end{array} & \begin{array}{l}\text { Move panel to skate trolley overhead crane } \\ \text { (SM6 SW) }\end{array}\end{array}$


TABLE 5: HIRADC Analysis Result.

\begin{tabular}{|c|c|c|c|c|c|}
\hline \multirow[t]{2}{*}{ Department } & \multirow[t]{2}{*}{ Total Risk } & \multicolumn{4}{|c|}{ Risk Level } \\
\hline & & Low & Moderate & High & $\begin{array}{l}\text { Extremely } \\
\text { High }\end{array}$ \\
\hline Packing \& Delivery & 153 & 145 & 5 & 3 & 0 \\
\hline Production MCCB & 35 & 25 & 10 & 0 & 0 \\
\hline Production CB & 40 & 18 & 19 & 3 & 0 \\
\hline Production ACB & 77 & 44 & 33 & 0 & 0 \\
\hline Production Busbar & 183 & 144 & 39 & 0 & 0 \\
\hline Emergency & 35 & 35 & 0 & 0 & 0 \\
\hline Production FQC LV & 92 & 75 & 17 & 0 & 0 \\
\hline Production FQC MV & 114 & 92 & 22 & 0 & 0 \\
\hline Production IQC & 125 & 111 & 14 & 0 & 0 \\
\hline Production LV & 376 & 276 & 100 & 0 & 0 \\
\hline Maintenance & 112 & 104 & 8 & 0 & 0 \\
\hline Production MC Set & 243 & 162 & 81 & 0 & 0 \\
\hline Motorpart & 288 & 191 & 97 & 0 & 0 \\
\hline Production PIX & 345 & 247 & 98 & 0 & 0 \\
\hline Production Recloser & 109 & 66 & 43 & 0 & 0 \\
\hline PoductionRM 6 & 174 & 98 & 76 & 0 & 0 \\
\hline Production SM6 CB & 787 & 552 & 235 & 0 & 0 \\
\hline Production SM6 SW & 636 & 463 & 173 & 0 & 0 \\
\hline Warehouse & 153 & 145 & 8 & 0 & 0 \\
\hline General Affair(GA) & 404 & 398 & 6 & 0 & 0 \\
\hline Total & 4481 & 3391 & 1084 & 6 & 0 \\
\hline Proportion & $100 \%$ & $75.68 \%$ & $24.19 \%$ & $0.13 \%$ & $0.00 \%$ \\
\hline
\end{tabular}

\section{No. HIRADC 2017}

3 Lift the trolley to lifting (Frame pane/ CB assy-SM6 CB)

4 Panel size isn't match with the trolley size (SM6)

5 There's no place the panel to interchange DMW process (Assy connection CB to deflector-SM6 CB)

6 There's no tightening CB place with the torsion process (Assy connection $\mathrm{CB}$ to deflector-SM6 CB)

7 Forklift operator isn't looking forward while driving the forklift (Kitting--Warehouse)
HIRADC 2018

There's no trolley lifting process lifting (Frame panel CB assy-SM6 CB)

There's safety tools to match panel with the trolley

Additional process - place the panel to interchange DMW (Assy connection CB to deflector-SM6 CB)

Additional process - tightening CB place with the torsion process (Assy connection CB to deflector-SM6 CB)

Forklift operator always looking forward while driving the forklift (Kitting--Warehouse) 
No. HIRADC 2017

8 No VT 3 phase checking process with 3 phase voltmeter (TTR-FQC MV)

9 The squatter operator when the TTR (FQC $\mathrm{MV}$ ) test process

10 No process to adjust panel with specifications (IP Check-FQC MV)

11 The process of installing tarpaulins on packing panels (packing)

12 The process of support CT support using rubber hammer (support CT preparation-Motorpact)

13 There is no process of inserting a panel into a Additionally the process of inserting a panel chest (finishing-reclose) into a chest (finishing-reclose)

14 There is no process of inserting the tank into the casket (finishing-reclose)

Additional process of inserting the tank into the casket (finishing-reclose)

15 There is no risk of back pain in the process of Additional risk of back pain in the process of installing CT cores (CT/VT assy- RM6) installing CT cores (CT/VT assy-RM6)

16 Process of moving CT/VT from trolley to Panel Change the process of moving CT/VT from (CT/VT assy-RM6)

17 Process of moving CT / VT from trolley to Panel (CT/VT assy-RM6)

18 There is no risk of noise compressor noisy on the process of using salt spray test machine for testing (salt spray test-IQC) trolley to jig

Change the process of moving CT/VT from jig to panel (CT/VT assy-RM6)

Additional noise risk of a noisy compressor in the process of using salt spray test machine for testing (salt spray test-IQC)

19 Activity of moving the busbar to the test table There is no activity to move the busbar to the manually (thickness plating test-IQC) test table manually (thickness plating test-IQC)

20 There is no process of putting a CT/VT box into a conveyor (DTR/TTR Test- IQC)

$21 \quad$ Activity use coolant for drilling process (drilling process-Busbar fabrication)

Additional process of putting CT/VT box into conveyor (DTR/TTR Test-IQC)

There is no coolant use activity for drilling process (drilling process-Busbar fabrication)

22 There is no Insul Boot process on Busbar Fabrication

23 There is no risk of goods falling on the packing process (ACB)

24 There is no risk of breakers falling on the repacking process (ACB)

25 There is a risk of tiptoe operators when putting cardboard on the top of the pile (repacking-MCCB)

26 Activity use coolant for drilling process (drilling process-Busbar fabrication)

Additional Insul Boot process on Busbar Fabrication

Additional risk of goods falling on the packing process (ACB)

Additional risk breakers fall on the repacking process (ACB)

There is no risk of tiptoe operators when laying cardboard on the top pile (repacking-MCCB)

There is no coolant use activity for drilling process (drilling process-Busbar fabrication)

27 Current control for any activity where there is Current control for any activity where there is a risk of sharp metal part is the use of gloves only a risk of sharp metal part is the use of gloves and long-sleeved shirts 


\section{Conclusion}

Results from HIRADC assessment show that as much as $75.68 \%$ of all potential hazards found in all activities or processes at Schneider Electric Cikarang have low risk level. A total of $\mathbf{2 4 . 1 9 \%}$ of all potential hazards found in all activities or processes at Schneider Electric Cikarang have a "moderate" risk level. The risk of hazard at the $95 \%$ moderate level is due to the rolling activity of the sleeve, so the operator is exposed to a sharp metal part. If these hazard risks can be overcome, then the potential hazard to moderate risk level may drop by $1.14 \%$. A total of $0.13 \%$ of all potential hazards found in all activities or processes at Schneider Electric Cikarang have a high risk level. As much as $0 \%$ of all potential hazards found in all activities or processes at Schneider Electric Cikarang have an "extremely high" risk level. Any activity or process that has potential risks with "moderate", "high" and "extremely high" risk levels will be followed up by the relevant departments and documented on OTP document.

\section{References}

[1] Robinson S, Arbez G, Birta LG, Tolk A, Wagner G. Conceptual modeling: definition purpose and benefits. In: 2015 Winter Simulation Conference (WSC). 2015 Winter Simulation Conference (WSC): 2015. Yilmaz L (Eds.). pp. 2812--2826. https:// ieeexplore.ieee.org/document/7408386

[2] International Labour Organization (ILO). Improving the safety and health of young workers. Geneva: United States; 2018. pp. 9--10. https://www. ilo.org/wcmsp5/groups/public/---ed_protect/---protrav/---safework/documents/ publication/wcms_625223.pdf

[3] Frick K. Worker influence on voluntary OHS management systems: A review of its ends and means. Safety Science 2011; 49(7): 974--987. https://www.sciencedirect. com/science/article/pii/S0925753511000907

[4] Granerud L, Rocha R. Organisational learning and continuous improvement of health and safety in certified manufacturers. Safety Science 2011; 49(7):1030--1039. https: //www.sciencedirect.com/science/article/pii/S0925753511000178

[5] Hasle P, Zwetsloot G. Editorial: Occupational health and safety management systems:

Issues and challenges. Safety Science 2011; 49(7):961--963. https://www.resear chgate.net/publication/241101416_Editorial_Occupational_Health_and_Safety_Man agement_Systems_Issues_and_challenges 
[6] Hohnen P, Hasle P. Making work environment auditable: A 'critical case' study of certified occupational health and safety management systems in Denmark. Safety Science 2011; 49(7):1022--1029. https://www.sciencedirect.com/science/article/pii/ S0925753510002833

[7] Nenonen S. Fatal workplace accidents in outsourced operations in the manufacturing industry. Safety Science 2011; 49(10):1394--1403. https://www.sciencedirect.com/ science/article/pii/S092575351100141X

[8] Rocha R. Institutional effects on occupational health and safety management systems. Human factor and ergonomics in manufacturing and service industries 2010; 20(3):211--225. https://www.researchgate.net/publication 229735834_Institutional_Effects_on_Occupational_Health_and_Safety_Management_Systems

[9] Underhill E, Quinlan M. How precarious employment affects health and safety at work: The case of temporary agency workers. Relations Industrielles 2011; 66(3):397-421. https://papers.ssrn.com/sol3/papers.cfm?abstract_id=1939452

[10] Gallagher C, Underhill E. Managing work health and safety: Recent developments and future directions. Asia Pacific Journal of Human Resources 2017; 50(5):227--244. https://onlinelibrary.wiley.com/doi/full/10.1111/j.1744-7941.2011.00014.x 